\title{
Pengaruh Pajak Daerah, Retribusi Daerah dan Produk Domestik Regional Bruto Terhadap Kapasitas Fiskal Kota Pontianak
}

\author{
Atria Tiffany Widyaningsih* \\ Akademi Perpajakan Panca Bhakti, Indonesia
}

\begin{abstract}
Based on regression equation result, local tax has negative influence to fiscal capacity so that if local tax increase IDR1 that impact decrease in fiscal cmcity equal to -27,449. It is stated that the rise and fall of the value of local tax realization has an effect on the income and allocation of expenditure of a region that support public expenditure infrastructure in fulfilling the economic requirement of society. The regional ratio has a negative influence on fiscal capacity so that if the regional retribution increases IDR1 resulted in a decrease in fiscal capacity of-28.216. This suggests that the rise and fall of the value of realization of regional levies affects the income of a region and the allocations of expenditure that support public expenditure infrastructure in meeting the economic needs of the community. PDRB has a positive influence on fiscal capacity so that if the PDRB increases IDR1 resulted in a decrease in fiscal capacity of 211,076,629.
\end{abstract}

Keywords: taxes, retribution, PDRB, fiscal capacity

\section{PENDAHULUAN}

Pajak Daerah yang dikelola pemerintah Kota Pontianak adalah pajak hotel, pajak restoran, pajak hiburan, pajak reklame, pajak penerangan jalan, pajak parkir, pajak sarang burung walet, pajak bumi dan bangunan, pedesaan dan perkotaan dan bea perolehan hak atas tanah dan bangunan. Untuk retribusi daerah digolongkan dalam tiga jenis yaitu retribusi jasa umum diatur dalam Peraturan Daerah No.4 Tahun 2011 tentang Retribusi Jasa Umum, retribusi jasa usaha diatur dalam Peraturan Daerah No.1 Tahun 2011 tentang Retribusi Jasa Usaha dan retribusi perizinan tertentu diatur dalam Peraturan Daerah No. 2 Tahun 2011 tentang Retribusi Perizinan Tertentu. Sedangkan PDRB merupakan jumlah total dari nilai barang dan jasa, atau nilai tambah bruto yang dihasilkan oleh seluruh unit ekonomi pada suatu wilayah/daerah (regional) itu sendiri yang merupakan salah satu indikator penting untuk mengetahui kondisi ekonomi di suatu daerah.

\footnotetext{
${ }^{*}$ E-mail : atria_tiffany@yahoo.co.id

Received : 5-6-2018, Accepted : 18-7-2018, Published : 30-12-2018

P-ISSN : 2087 - 9954, E-ISSN : 2550 - 0066. DOI:http://dx.doi.org/10.26418/jebik.v7i3.25893
} 
Kapasitas fiskal daerah yang selanjutnya disebut kapasitas fiskal adalah gambaran kemampuan keuangan masing-masing daerah yang dicerminkan melalui penerimaan umum Anggaran Pendapatan dan Belanja Daerah (APBD) tidak termasuk Dana Alokasi Khusus (DAK), dana darurat, dana pinjaman lama, dan penerimaan lain yang penggunaannya dibatasi dalam biaya pengeluaran tertentu untuk membiayai tugas pemerintahan setelah dikurangi belanja pegawai dan dikaitkan dengan jumlah penduduk miskin. APBD menjadi implenetasi rencana keuangan tahunan pemerintahan daerah yang dibahas dan disetujui bersama oleh Pemerintah Daerah dan Dewan Perwakilan Rakyat Daerah yang ditetapkan dengan Peraturan Daerah.

Kalimantan Barat memiliki peran penting dalam pembangunan di Indonesia. Koridor ekonomi Kalimantan Barat memiliki potensi dan sentra produksi dan energi dari Lumbung Energi Nasional. Secara geostrategis, Kalimantan Barat diharapkan menjadi gerbang ekonomi nasional di Pasar Asia Tenggara sehingga dapat meningkatkan PDRB.

Tabel 1. Penerimaan Pajak Daerah, Retribusi Daerah, PDRB dan Kapasitas Fiskal Daerah Kota Pontianak Tahun 2012 s/d 2016 (dalam rupiah)

\begin{tabular}{llccr}
\hline Tahun & Pajak Daerah (X1) & Retribusi Daerah(X2) & $\begin{array}{c}\text { PDRB (Harga } \\
\text { Berlaku) X3 }\end{array}$ & Kapasitas Fiskal (Y) \\
\hline 2012 & $162.782 .492 .225,00$ & $26.992 .841 .239,50$ & $16.898 .967,46$ & $738.939 .662 .312,37$ \\
\hline 2013 & $179.655 .427 .197,00$ & $53.412 .352 .739,63$ & $19.385 .994,54$ & $38.142 .477 .476,77$ \\
\hline 2014 & $203.165 .655 .899,00$ & $49.752 .244 .887,37$ & $22.349 .613,91$ & $31.206 .207 .178,91$ \\
\hline 2015 & $240.452 .113 .349,00$ & $32.821 .997 .143,00$ & $25.076 .492,61$ & $35.224 .468 .465,61$ \\
\hline 2016 & $258.149 .996 .119,00$ & $42.016 .497 .122,00$ & $27.593 .291,28$ & $17.528 .808 .900,38$ \\
\hline
\end{tabular}

Penerimaan pajak daerah sudah mengalami peningkatan karena setiap jumlah target dan realisasi pencapaiannya memiliki selisih yang tidak terlalu besar, serta jumlah penerimaan yang ditargetkan dari tahun ke tahun mengalami peningkatan khususnya pada tahun 2016. Untuk retribusi daerah tertinggi tahun 2013 dan pada akhirnya banyak retribusi Rp 0 yang telah diberlakukan oleh Pemkot Pontianak menjelang Tahun 2015. Peningkatan PDRB walau belum dikatakan maksimal namun potensi terbesar dimiliki adalah sektor perdagangan, hotel dan restauran hampir 35\%. Peta kapasitas fiskal daerah menurun setiap tahunnya dan ini sebaiknya memerlukan perhatian khusus untuk pengusulan pemerintah daerah sebagai penerima hibah, penilaian atas usulan pinjaman daerah serta penentuan besaran dana pendamping,

Penelitian ini bertujuan untuk mengetahui pengaruh pajak daerah, retribusi daerah dan produk domestik regional bruto terhadap kapasitas fiskal secara bersama sama dan parsial Kota Pontianak dari tahun 2012-2016. Adapun kontribusi penelitian ini dapat digunakan oleh pemerintah, masyarakat dan penulis sebagai dasar untuk mengetahui perkembangan pajak daerah, retribusi daerah, PDRB serta kapasitas fiskal guna 
meningkatkan pertumbuhan ekonomi serta pemberian solusi yang aktif atas permasalahan yang dihadapi.

\section{KAJIAN LITERATUR}

Kemajuan suatu negara atau daerah dapat dilihat dari tingkat pembangunan yang dilaksanakan oleh pemerintah demi kesejahteraan masyarakat dengan infrastruktur yang baik. Untuk memfasilitasi semua pembangunan yang akan dilaksanakan oleh pemerintah, diperlukannya sumber biaya yang besar. Sumber pendapatan suatu negara maupun daerah adalah pajak dan retribusi yang merupakan sumber pendapatan terpenting yang dipungut pemerintah dari masyarakat untuk menutupi biaya pembangunannya serta tingkat produk domestik regional bruto yang disajikan untuk mengetahui tingkat ekonomi suatu daerah. Semakin besar penerimaan suatu negara atau daerah, maka akan semakin besar pula tingkat pembangunan yang akan terlaksana, baik dari pajak, retribusi maupun tingkat produk domestik regional bruto yang menjadi potensi utama kemakmuran suatu negara atau daerah.

Ciri utama yang menunjukkan suatu daerah mampu berotonomi terletak pada kemampuan keuangan daerah. Artinya, daerah otonom harus mempunyai kemampuan untuk menggali sumber-sumber keuangan sendiri, mengelola dan menggunakan keuangan sendiri untuk membiayai penyelenggaraan pemerintahan daerahnya (Mafaza, W., Mayowan, Y., Sasetiadi., 2016).

\subsection{Pengaruh}

Dalam Kamus Besar Bahasa Indonesia,Pengaruh adalah suatu daya yang ada atau timbul dari seseorang ataupun benda yang ikut membentuk watak, kepercayaan atau perbuatan seseorang. Pengaruh adalah suatu keadaan yang memiliki hubungan timbal balik atau hubungan sebab akibat antara apa yang mempengaruhi dengan apa yang di pengaruhi, jika salah satu yang disebut pengaruh tersebut berubah maka akan ada akibat yang ditimbulkannya.

\subsection{Pajak Daerah}

Secara teoritis menurut (Sari, 2013), Pajak adalah iuran pada negara (yang dapat dipaksakan yang terutang oleh yang wajib membayarnya menurut peraturan-peraturan dengan tidak mendapat prestasi kembali, yang langsung dapat ditunjuk dan yang gunanya adalah untuk membiayai pengeluaran-pengeluaran umum berhubungan dengan tugas pemerintah. Dari segi pemungutannya, pajak dibagi menjadi dua yaitu pajak pusat dan pajak daerah. Pajak pusat adalah pajak yang dipungut oleh pemerintah pusat yang menyelenggarakan pemungutan di daerah dilakukan oleh Kantor Pelayanan Pajak setempat yang hasilnya digunakan untuk membiayai pengeluaran negara. Sedangkan pajak daerah adalah pajak yang wewenang pemungutannya berada pada pemerintah daerah baik provinsi maupun kota atau kabupaten untuk membiayai pengeluaran daerahnya. 
Setelah dikeluarkan Undang-Undang yang baru yaitu Undang-Undang No.28 Tahun 2009, pengaturan pajak dan retribusi daerah lebih limitatif, dilakukan perluasan basis pajak dan jenis retribusi yang menjadi kewenangan daerah. Sumber-sumber pembiayaan yang diserahkan kepada daerah itu nantinya akan dimanifestasikan lewat struktur Pendapatan Asli Daerah (PAD) yang kuat. PAD inilah sumber pembiayaan yang memang benar-benar digali dari daerah itu sendiri sehingga dapat mencerminkan kondisi riil daerah. Jika nantinya struktur PAD sudah kuat, boleh dikatakan daerah tersebut memiliki kemampuan pembiayaan yang juga kuat. Untuk itu tentu dibutuhkan suatu struktur industri yang mantap beserta obyek pajak dan retribusi yang taat (Sunarto \& Sunyoto, 2016).

Komponen sumber PAD tersebut khususnya pajak daerah dan retribusi daerah diharapkan dapat memberikan kontribusi yang positif untuk peningkatan PAD menjelaskan bahwa peranan sektor pajak daerah dan retribusi yang paling besar kontribusinya terhadap PAD, yang dimana pengelolaannya diserahkan kepada pemerintah daerah itu sendiri. Dalam menyelenggarakan pembangunan di daerahnya, faktor sumber pendapatan daerah dan retribusi daerah sangat menentukan terlaksananya pembangunan daerah itu sendiri (Kusuma, M.K.A.A \& Wirawati, 2013).

\subsection{Retribusi Daerah}

Pasal 108 ayat (1) Undang-Undang No. 28 Tahun 2009 menyebutkan terdapat tiga jenis objek retribusi yaitu : 1). Objek Retribusi Jasa Umum, sebagaimana diatur dalam Pasal 109 Undang-Undang No.28 Tahun 2009, adalah pelayanan yang disediakan atau diberikan pemerintah daerah untuk tujuan kepentingan dan kemanfaatan umum serta dapat dinikmati oleh orang pribadi atau badan ; 2). Objek Retribusi Jasa Usaha, sebagaimana diatur dalam Pasal 126 Undang-Undang No.28 Tahun 2009, adalah pelayanan yang disediakan oleh pemerintah daerah dengan menganut prinsip komersial yang meliputi pelayanan dengan memanfaatkan keuangan daerah yang belum dimanfaatkan secara optimal dan pelayanan oleh pemerintah daerah sepanjang belum disediakan secara memadai oleh pihak swasta ; 3). Objek Retribusi Perizinan Tertentu, sebagaimana diatur dalam Pasal 140 Undang-Undang No.28 Tahun 2009, adalah pelayanan perizinan tertentu oleh pemerintah daerah kepada orang pribadi atau badan yang dimaksudkan untuk pengaturan dan pengawasan atas kegiatan pemanfaatan ruang, sumber daya alam, barang, sarana dan prasarana atau fasilitas tertentu guna melindungi kepentingan umum dan menjaga kelestarian lingkungan.

Pajak daerah dan retribusi daerah mempengaruhi kemandirian daerah dan juga dapat mempengaruhi pertumbuhan ekonomi daerah. Pajak dan retribusi daerah yang tinggi berarti jumlah uang yang masuk ke kas daerah semakin banyak, sehingga pemerintah daerah berupaya untuk memajukan perekonomian daerahnya. 


\subsection{Produk Domestik Regional Bruto}

Pertumbuhan ekonomi berkaitan dengan proses peningkatan produksi barang dan jasa pada kegiatan ekonomi masyarakat dan diukul melalui PDB berdasarkan harga konstan, supaya angka pertumbuhan yang dihasilkan ada pertambahan produksi (Dewi, J.K., Budhi, 2018). Perkembangan PDRB atas dasar harga berlaku dari tahun ke tahun menggambarkan perkembangan yang disebabkan oleh adanya perubahan dalam volume produksi barang dan jasa yang dihasilkan dan perubahan dalam tingkat harganya dan menunjukkan pendapatan yang dapat dinikmati oleh penduduk suatu daerah serta menggambarkan nilai tambah barang dan jasa yang dihitung menggunakan harga pada setiap tahun. Salah satu faktor yang mendorong investor melakukan investasi di suatu daerah adalah karena faktor ekonomi di daerah tujuan, seperti potensi pasar, sumber daya alam dan daya saing. Potensi pasar digambarkan dengan besarnya pendapatan daerah tersebut yang dicerminkan oleh nilai PDRB (Habiburrahman, 2012)

Produk Domestik Regional Bruto (PDRB) merupakan nilai tambah bruto seluruh barang dan jasa yang dihasilkan di wilayah domestik suatu negara yang timbul akibat berbagai aktivitas ekonomi dalam periode tertentu. Penyusunan PDRB dilakukan melalui 3 (tiga) pendekatan yaitu pendekatan produksi, pengeluaran dan pendapatan. Pendekatan Produksi dapat disebut juga pendekatan nilai tambah dimana nilai tambah bruto (NTB) dengan cara mengurangkan nilai output yang dihasilkan oleh seluruh kegiatan ekonomi dengan biaya antara dari masing-masing nilai produksi bruto tiap sektor ekonomi. Nilai tambah merupakan nilai yang ditambahkan pada barang dan jasa yang dipakai oleh unit produksi sebagai input antara. Nilai yang ditambahkan sama dengan balas jasa faktor produksi atas ikutsertanya dalam proses produksi.

Unit-unit produksi dalam penyajian ini dikelompokkan dalam 9 lapangan usaha (sektor) sesuai dengan International Standard Industrial Classification of All Economic Activities (ISIC), yaitu: Pertanian, Peternakan, Kehutanan dan Perikanan; Pertambangan dan Penggalian; Industri Pengolahan; Listrik, Gas dan Air Bersih; Konstruksi; Perdagangan, Hotel dan Restoran; Pengangkutandan Komunikasi; Keuangan, Real Estate dan Jasa Perusahaan serta Jasa-jasa (termasuk jasa pemerintah).

Pada pendekatan pendapatan, nilai tambah dari kegiatan-kegiatan ekonomi dihitung dengan cara menjumlahkan semua balas jasa faktor produksi yaitu upah dan gaji, surplus usaha, penyusutan dan pajak tak langsung neto (pajak tak langsung dikurangi subsidi). Untuk sektor pemerintahan dan usaha yang sifatnya tidak mencari keuntungan, surplus usaha (bunga neto, sewa tanah dan keuntungan) tidak diperhitungkan.

Pendekatan pengeluaran digunakan untuk menghitung nilai barang dan jasa yang digunakan oleh berbagai golongan dalam masyarakat untuk keperluan konsumsi rumah tangga, pemerintah, yayasan sosial, pembentukan modal dan ekspor. Mengingat nilai barang dan jasa hanya berasal dari produksi domestik, total pengeluaran dari komponen 
diatas harus dikurangi nilai impor sehingga nilai ekspor yang dimaksud adalah ekspor neto. Penjumlahan seluruh komponen pengeluaran akhir ini disebut PDRB atas dasar harga pasar.

Data pendapatan nasional adalah salah satu indikator makro yang dapat menunjukkan kondisi perekonomian setiap tahunnya. Manfaat yang dapat diperoleh dari data ini antara lain: 1). PDRB harga berlaku menunjukkan kemampuan sunber daya ekonomi yang dihasilkan oleh suatu wilayah ; 2). PDRB harga konstan digunakan untuk menunjukkan laju pertumbuhan ekonomi secara keseluruhan per tahun ; 3). Distribusi PDRB harga berlaku menurut lapangan usaha menunjukkan struktur perekonomian atau peranan setiap kategori ekonomi dalam suatu wilayah ; 4). PDRB per kapita atas dasar berlaku menunjukkan nilai PDB dan PNB per satu orang penduduk ; 5). PDRB per kapita atas dasar harga konstan berguna untuk mengetahui pertumbuhan nyata ekonomi per kapita penduduk suatu negara.

Produk Domestik Regional Neto (PDRN) merupakan produk domestik regional bruto yang dikurangi penyusutan barang modal yang terjadi selama proses produksi atau adanya pajak tidak langsung yang dipungut pemerintah dan subsidi yang diberikan oleh pemerintah kepada unit produksi. Pendapatan regional merupakan PDRN dikurangi dengan pendapatan yang mengalir ke luar dan ditambah dengan pendapatan yang mengalir ke dalam daerah. Ekspor barang dan impor merupakan kegiatan transaksi barang dan jasa antara penduduk daerah dengan penduduk daerah lain.

Selain dari sektoral, perkembangan ekonomi dapat juga tercermin dari komponen-komponen penggunaan PDRB yang menggambarkan komposisi penggunaan barang dan jasa, baik yang dihasilkan didalam maupun diluar daerah. Komponenkomponen tersebut terdiri dari: pengeluaran konsumsi rumah tangga dan lembaga swasta, konsumsi pemerintah, pembentukan modal tetap domestik bruto, perubahan inventaris, ekspor neto (ekspor dikurangi impor).

Jumlah penduduk Kota Pontianak sebanyak 607.438 jiwa yang tersebar di enam kecamatan. Penduduk terbanyak adalah Kecamatan Pontianak Barat sebanyak 136.883 jiwa, diikuti Kecamatan Pontianak Kota sebanyak 126.099 jiwa dan Kecamatan Pontianak Utara sebanyak 110.471 jiwa. Pada tahun 2015, PDRB atas dasar harga berlaku Kota Pontianak sebesar 27.593,29 milyar rupiah, PDRB tertinggi berada di Kecamatan Pontianak Selatan sebesar 7.492,31 milyar rupiah diikuti oleh Kecamatan Pontianak Kota sebesar 6.799,02 milyar rupiah dan diurutan ketiga berada di Kecamatan Pontianak Barat sebesar 4.710,02 milyar rupiah.

\subsection{Kapasitas Fiskal}

Pertumbuhan ekonomi merupakan parameter dari suatu kegiatan pembangunan, hal ini dikarenakan pertumbuhan ekonomi dapat mengukur tingkat perkembangan aktivitas pada sektor-sektor ekonomi dalam suatu perekonomian (Juwari, J., Djoko, S., 
Yana, 2016). Kapasitas Fiskal (fiscal capacity) merupakan suatu komponen yang termasuk dalam formula perhitungan Dana Alokasi Umum (DAU). DAU merupakan salah satu komponen didalam dana perimbangan di APBN yang pengalokasiannya didasarkan atas formula dengan konsep kesenjangan fiskal (fiscal gap).

Dalam Peraturan Menteri Keuangan Republik Indonesia No.54/PMK.07/2014 tentang Peta Kapasitas Fiskal sebagaimana telah diubah menjadi Peraturan Menteri Keuangan Republik Indonesia No.33/PMK.07/2015 dan terakhir diubah dalam Peraturan Menteri Keuangan Republik Indonesia No.37/PMK.07/2016 tentang Peta Kapasitas Fiskal, kapasitas fiskal merupakan gambaran kemampuan keuangan suatu daerah yang dicerminkan melalui penerimaan umum Anggaran Pendapatan dan Belanja Daerah (tidak termasuk dana alokasi khusus, dana darurat, dana pinjaman lama dan penerimaan lain yang penggunaannya dibatasi untuk membiayai pengeluaran tertentu) untuk membiayai tugas pemerintahan setelah dikurangi belanja pegawai dan dikaitkan dengan jumlah penduduk miskin.

Kebijaksanaan untuk mengatasi kesenjangan fiskal antar daerah dilakukan dengan transfer dana dari pemerintah pusat kepada daerah melalui konsep fiscal gap yaitu kebutuhan daerah (kebutuhan fiskal) dibandingkan dengan potensi daerah (kapasitas fiskal). Kebutuhan daerah yang melebihi kapasitas fiskal akan ditutup dengan transfer dana dari Pemerintah Pusat. Dana Alokasi Umum yang disalurkan kepada Propinsi dan Kabupaten/Kota dapat meningkatkan kemampuan kapasitas fiskal daerah (Herdaleny, A., Badjuri, Prianto, 2015).

Penerapan desentralisasi fiskal memberikan konsekuensi-konsekuensi, yaitu di setiap daerah dituntut untuk membiayai seluruh pengeluaran daerah, namun tidak semua daerah mampu membiayai pengeluaran pemerintah daerah menggunakan Pendapatan Asli Daerah (PAD), dikarenakan kemampuan daerah untuk menyediakan pendanaan yang berasal dari daerah sangat tergantung pada kemampuan merealisasikan potensi ekonomi tersebut menjadi bentuk-bentuk kegiatan ekonomi yang mampu menciptakan perguliran dana untuk pembangunan daerah yang berkelanjutan (Widani, C. I. K, \& Erawati, 2016).

Dalam meningkatkan kemandirian daerah, pemerintah daerah harus berupaya terus-menerus dalam menggali dan meningkatkan sumber keuangan daerahnya sendiri sesuai dengan potensinya. Untuk mendukung upaya peningkatan PAD, perlu diadakan pengukuran atau penilaian sumber-sumber PAD agar dapat dipungut secara berkesinambungan tanpa memperburuk alokasi faktor produksi serta dapat pula dilakukan dengan meningkatkan jumlah obyek dan subyek pajak dan/atau retribusi daerah.

Dalam rangka penciptakan good governance dengan akuntabilitas publik yang kuat, maka laporan keuangan pemerintah daerah yang dihasilkan tersebut harus diupayakan untuk dapat secara sederhana dianalisis keterukurannya (akuntable) dan 
diakses dengan mudah (transparan) oleh umum (publik) dalam format yang lebih sederhana pada setiap variabel sesuai dengan sistem dan standar akuntansi (Chodariyanti, 2015).

Dalam rangka mendukung sumber pembiayaan pembangunan daerah, perlu dikembangkan kebijakan fiskal dengan memperhatikan prinsip keadilan, efisiensi, dan efektifitas untuk menambah penerimaan daerah tersebut. Sejalan dengan kebijakan fiskal pajak dan retribusi merupakan sumber pendapatan daerah yang penting guna membiayai penyelenggaraan pemerintah dan pembangunan untuk melaksanakan otonomi daerah yang nyata, dinamis, serasi dan bertanggung jawab (Nurhayati, 2016).

Sebagian negara-negara maju, kapasitas fiskal diperkirakan menggunakan basis pajak-pajak utama dan tingkat tarif pajak standar (rata-rata). Metode ini mengukur kapasitas fiskal suatu daerah dari penerimaan yang dapat dihimpun seandainya daerah tersebut memajaki semua basis pajak standarnya dengan upaya pajak (tax effort) yang standar pula. Metode ini cenderung menggunakan tingkat pajak standar (nasional) dari pada menggunakan tingkat pajak efektif daerah yang bersangkutan untuk menghindari terjadinya hukuman terhadap daerah yang memiliki upaya pajak (tax effort) tinggi dan merangsang (encourage) daerah yang tax effort-nya rendah. Dengan kata lain, apabila tingkat pajak efektif suatu daerah lebih tinggi dari rata-rata nasional, transfer yang diterimanya tidak menjadi berkurang dan bila tingkat pajak efektif daerah lebih rendah dari rata-rata nasional, transfer yang diperolehnya tidak menjadi bertambah.

Metode pengukuran kapasitas fiskal ini membutuhkan data yang lengkap, akurat dan detil sehingga sulit untuk dipenuhi terutama di negara-negara berkembang. Oleh karena itu, kapasitas fiskal sering diukur dengan menggunakan variabel atau indikator lain, diantaranya yang pertama yaitu Produk Domestik Regional Bruto (PDRB). Kapasitas fiskal daerah yang dapat diukur dengan mengalikan PDRB terhadap rasio penerimaan PDB standar (standard revenue/ personal incomeratio), dimana rasio standar merupakan rata-rata nasional ataupun rata-rata dari beberapa kelompok daerah. Kelemahan utama dari cara ini adalah indikator PDRB cenderung mengabaikan kenyataan bahwa struktur perekonomian yang berbeda antar daerah bisa memiliki dampak yang signifikan terhadap kemampuan daerah untuk menghimpun pendapatan, misalnya PDRB per kapita yang sama dan daerah sektor pertaniannya yang lebih dominan bisa memiliki potensi pendapatan pajak lebih rendah dibanding daerah lainnya yang didominasi sektor manufaktur dan jasa-jasa.

Kedua, yaitu pendapatan perorangan (jumlahan dari seluruh pendapatan penduduk setempat). Kapasitas fiskal daerah dapat juga diukur dari total pendapatan perorangan dikalikan dengan rasio standar dari penerimaan terhadap pendapatan perorangan (standard revenue/personal income ratio). Tentu saja cara ini bukan ukuran untuk menentukan kapasitas fiskal yang sempurna, mengingat pendapatan perorangan hanya salah satu dari sumber penerimaan yang tidak proporsional dengan jumlah seluruh basis pajak. 
Ketiga, adalah jumlah penjualan ritel di daerah. Apabila pajak yang didasarkan atas konsumsi penting sebagai sumber penerimaan untuk daerah, ini bisa dijadikan proksi yang baik bagi basis pajaknya. Kapasitas fiskal diukur dengan mengalikan jumlah penjualan ritel dengan rasio penerimaan terhadap total penjualan standar (standard revenue to total retail sales ratio).

Berdasarkan Peraturan Menteri Keuangan Republik Indonesia No.37/PMK.07/2016 tentang Peta Kapasitas Fiskal (Menteri Keuangan, 2017), penyusunan peta Kapasitas Fiskal daerah Provinsi dan daerah Kabupaten/Kota dilakukan dengan 2 tahap, yaitu perhitungan Kapasitas Fiskal daerah Provinsi dan Daerah Kabupaten/Kota sebagaimana dimaksud dalam pasal 3 huruf a dan perhitungan Indeks Kapastas Fiskal daerah Provinsi dan Daerah Kabupaten/Kota sebagaimana dimaksud dalam pasal 3 huruf $b$. Bentuk umum dari formula perhitungan kapasitas fiskal:

$$
\mathrm{KF}=\frac{(\mathrm{PAD}+\mathrm{DAU}+\mathrm{DBH}+\text { Otsus }+ \text { Transfer Prov }+\mathrm{LP})-\mathrm{BP}}{\text { Jumlah Penduduk Miskin }}
$$

dimana :

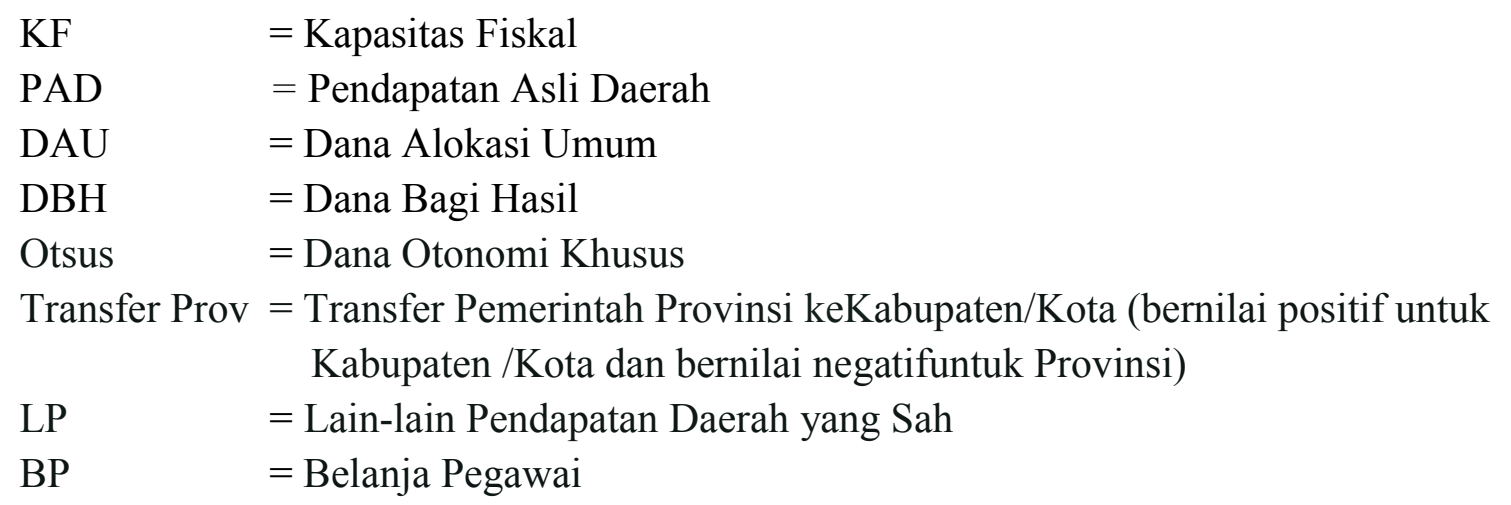

Sedangkan untuk perhitungan kapasitas fiskal yang digunakan dalam menentukan besarnya kapasitas fiskal Kota Pontianak, peneliti mengunakan besarnya pendapatan daerah, belanja daerah, penerimaan pembiayaan daerah dan pengeluaran pembiayaan sebagai dasar hitung dengan rumus sebagai berikut:

$$
\mathrm{KF}=(\mathrm{PAD}+\text { PenBiaya })-(\mathrm{BD}+\text { Peng.Biaya })
$$

dimana :

$\begin{array}{ll}\mathrm{KF} & =\text { Kapasitas Fiskal } \\ \mathrm{PAD} & =\text { Pendapatan Asli Daerah } \\ \text { PenBiaya } & =\text { Penerimaan Pembiayaan } \\ \mathrm{BD} & =\text { Belanja Daerah } \\ \text { PengBiaya } & =\text { Pengeluaran Pembiayaan }\end{array}$


Potensi keuangan daerah yang tidak sama menimbulkan adanya kesenjangan keuangan yang dapat mengakibatkan kesenjangan pembangunan antar daerah. Untuk mengurangi kesenjangan dan untuk mendukung penyelenggaraan otonomi daerah melalui penyediaan sumber-sumber pendanaan, lahirlah Undang-Undang Nomor 25 Tahun 1999 yang terakhir diubah dengan Undang-Undang No. 33 Tahun 2004 tentang Perimbangan Keuangan antara Pemerintah pusat dan Pemerintah daerah (Fiona, L., Taufik, T, \& Ratnawati, 2016). Perhitungan kapasitas fiskal didasarkan pada data realisasi APBD sesuai dengan Peraturan Menteri Keuangan mengenai sistem akuntansi pemerintah, sedangkan penghitungan indeks kapasitas fiskal daerah provinsi dilakukan dengan menghitung kapasitas fiskal masing-masing daerah provinsi dan kabupaten/kota yang dibagi dengan rata-rata kapasitas fiskal seluruh daerah.

Sebagaimana telah dimaksud pada ayat (6) dan ayat (7), Indeks Kapasitas Fiskal daerah dikelompokkan dalam 4 (empat) kategori kapasitas fiskal sebagai berikut: 1) Daerah yang indeks kapasitas fiskalnya lebih dari atau sama dengan 2 (indeks 2) merupakan daerah yang termasuk kategori kapasitas fiskal sangat tinggi ; 2). Daerah yang indeks kapasitas fiskalnya antara lebih dari atau sama dengan 1 sampai kurang dari 2 ( 1 indeks $<2$ ) merupakan daerah yang termasuk kategori kapasitas fiskal tinggi ; 3 ). Daerah yang indeks kapasitas fiskalnya antara lebih dari 0,5 sampai kurang dari $1(0,5$ $<$ indeks $<1)$ merupakan daerah yang termasuk kategori kapasitas fiskal sedang; 4). Daerah yang indeks kapasitas fiskalnya kurang dari atau sama dengan 0,5 (indeks $<0,5)$ merupakan daerah yang termasuk kategori kapasitas fiskal rendah.

Tujuan dari perhitungan kapasitas fiskal, selain untuk mengetahui seberapa besar tingkat kemampuan suatu daerah dalam membiayai pembangunannya sendiri tanpa bantuan dari pemerintah pusat, juga dimaksudkan untuk mengetahui seberapa besar anggaran DAU yang disediakan pemerintah pusat yang akan diberikan kepada daerahdaerah provinsi untuk membantu membiayai pembangunan daerah karena dianggap dalam sistem otonomi daerah ini daerah provinsi masih belum sepenuhnya mampu untuk mandiri dalam membiayai semua kegiatan pembangunan daerah. Kapasitas fiskal yang buruk merusak kepercayaan masyarakat terhadap pemerintah dan lembaga yang lain. Buruknya pelayanan pemerintah mempengaruhi ketidakpuasan dan ketidakpercayaan, terutama pada masyarakat miskin. Hal ini dikarenakan orang-orang berpenghasilan rendah sangat bergantung pada layanan pemerintah sebagai kebutuhan dasar (seperti pendidikan dan kesehatan). Kurangnya kepercayaan memiliki konsekuensi ekonomi, yaitu ketika orang memandang bahwa sistem sosial yang tidak dipercaya dan tidak adil, hal ini dapat mempengaruhi insentif untuk terlibat dalam kegiatan produktif (Rauf, 2016). Hipotesis dalam penelitian ini :

Hipotesis $1(\mathrm{H} 1)$ = Pajak Daerah mempunyai dampak positif terhadap Kapasitas Fiskal Daerah

Hipotesis 2 (H2) = Retribusi daerah mempunyai dampak negatif terhadap Kapasitas Fiskal Daerah

Hipotesis $3(\mathrm{H} 3)$ = PDRB mempunyai dampak positif terhadap Kapasitas Fiskal Daerah 


\section{METODA PENELITIAN}

Penelitian ini termasuk penelitian terapan yang bertujuan untuk memecahkan masalah-masalah praktis dari keuangan daerah dengan variabel pajak daerah, retribusi daerah,PDRB dan kapasitas fiskal daerah dari tahun 2012 sampai 2016. Alat analisis menggunakan uji regresi menggunakan SPSS. Teknik pengumpulan data yang digunakan menggunakan wawancara, observasi dan dokumentasi.

\subsection{Model Regresi}

Rumus persamaan regresi yang digunakan adalah persamaan regresi tiga prediktor, yaitu:

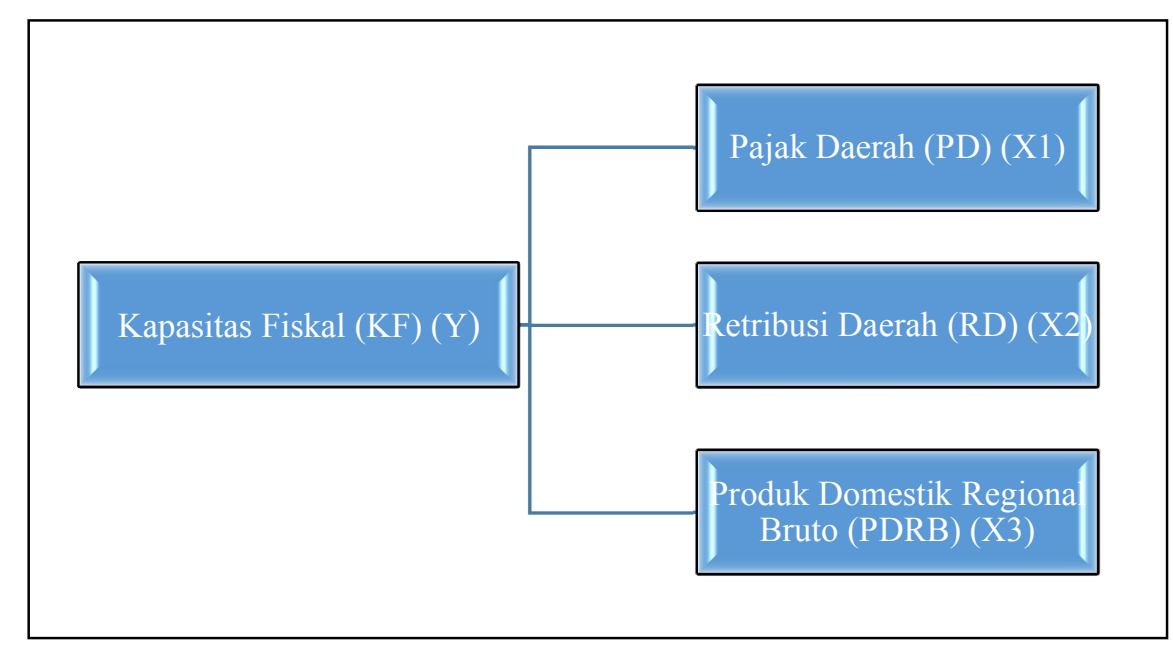

Gambar 1. Model Penelitian

$$
\mathrm{Y}=\mathrm{a}+\mathrm{b}_{1} \mathrm{X}_{1}+\mathrm{b}_{2} \mathrm{X}_{2}+\mathrm{b}_{3} \mathrm{X}_{3}
$$

dimana :

$\mathrm{Y}=$ Kapasitas Fiskal

$\mathrm{a}=$ Nilai Konstan

$\mathrm{b}=$ Nilai Koefesien

$\mathrm{X}_{1}=$ Pajak Daerah

$\mathrm{X}_{2}=$ Retribusi Daerah

$\mathrm{X}_{3}=$ Produk Domestik Regional Bruto (PDRB)

\section{HASIL PENELITIAN DAN PEMBAHASAN}

\subsection{Pengujian Pajak Daerah, Retribusi Daerah dan Produk Domestik Regional Bruto Terhadap Kapasitas Fiskal Kota Pontianak}

Dari Tabel 1 diketahui bahwa variabel independen terdiri dari 3 (tiga) variabel yaitu variabel pajak daerah $\left(\mathrm{X}_{1}\right)$, retribusi daerah $\left(\mathrm{X}_{2}\right)$ dan PDRB $\left(\mathrm{X}_{3}\right)$, sedangkan untuk 
variabel dependen adalah variabel kapasitas fiskal (Y) dengan hasil analisis sebagai berikut:

\section{Analisis Statistik Deskriptif}

Analisis deskriptif dilakukan dengan tujuan untuk mendapatkan gambaran yang lebih jelas tentang data yang diperoleh dalam sebuah penelitian, kemudian data tersebut dianalisis untuk mengetahui pengaruh variabel bebas (independen) terhadap variabel terikat (dependen). Berikut ini disajikan Tabel 2 tentang hasil dari perhitungan statistik deskriptif dari masing-masing variabel.

Tabel 2. Descriptive Statistics

\begin{tabular}{|c|c|c|c|c|c|}
\hline & $\mathrm{N}$ & Minimum & Maximum & Mean & $\begin{array}{c}\text { Std. } \\
\text { Deviation }\end{array}$ \\
\hline Pajak Daerah & 5 & $\begin{array}{r}162.782 .492 .2 \\
25,00\end{array}$ & $\begin{array}{l}258.149 .9 \\
96.119,00\end{array}$ & $\begin{array}{l}208.841 .13 \\
6.957,8000\end{array}$ & $\begin{array}{r}40.112 .44 \\
4.809,238 \\
44\end{array}$ \\
\hline Retribusi Daerah & 5 & $\begin{array}{r}26.992 .841 .23 \\
9,50\end{array}$ & $\begin{array}{r}53.412 .35 \\
2.739,63\end{array}$ & $\begin{array}{r}40.999 .124 \\
226,3000\end{array}$ & $\begin{array}{r}11.121 .83 \\
0.011,377 \\
23\end{array}$ \\
\hline PDRB & 5 & $16.898 .967,46$ & $\begin{array}{r}27.593 .29 \\
1,27\end{array}$ & $\begin{array}{r}22.260 .871 \\
9640\end{array}$ & $\begin{array}{r}4.283 .258 \\
99821\end{array}$ \\
\hline Kapasitas Fiskal & 5 & $\begin{array}{r}17.528 .808 .90 \\
0,38\end{array}$ & $\begin{array}{l}738.939 .6 \\
62.312,37\end{array}$ & $\begin{array}{l}172.208 .32 \\
4.866,8080\end{array}$ & $\begin{array}{r}316.910 .8 \\
65.641,21 \\
967\end{array}$ \\
\hline $\begin{array}{l}\text { Valid N } \\
\text { (listwise) }\end{array}$ & 5 & & & & \\
\hline
\end{tabular}

Hasil perhitungan Tabel 2, variabel pajak daerah menunjukkan nilai maksimum sebesar Rp 258.149.996.119,00 dan nilai minimumnya sebesar Rp 162.782.492.225,00 dari jumlah data yang digunakan $(\mathrm{N})$ sebanyak 5, sehingga diperoleh nilai rata-rata sebesar Rp 208.841.136.957,8000. Sedangkan untuk nilai standar deviasinya yaitu sebesar Rp 40.112.444.809,23844 yang menggambarkan seberapa besar perbedaan nilai variabel terhadap rata-rata. Semakin besar nilai standar deviasi maka data variabel semakin menyebar atau bervariasi.

Pada variabel retribusi daerah menunjukkan nilai maksimum sebesar Rp 53.412.352.739,63 dan nilai minimumnya sebesar Rp 26.992.841.239,50 dari jumlah data yang digunakan $(\mathrm{N})$ sebanyak 5, sehingga dari tabel diperoleh nilai rata-rata sebesar Rp 40.999.124.226,3000. Sedangkan untuk nilai standar deviasinya yaitu sebesar $R p$ 11.121.830.011,37723. Variabel PDRB menunjukkan nilai maksimum sebesar Rp.27.593.291,27 dan nilai minimumnya sebesar Rp 16.898.967,46 dari jumlah data yang digunakan $(\mathrm{N})$ sebanyak 5, sehingga diperoleh nilai rata-rata sebesar $\mathrm{Rp}$ 22.260.871,9640. Sedangkan untuk nilai standar deviasinya yaitu sebesar Rp 4.283.258,99821. Variabel kapasitas fiskal menunjukkan nilai maksimum sebesar 
Rp 738.939.662.312,37 dan nilai minimumnya sebesar $\mathrm{Rp}$ 17.528.808.900,38 dari jumlah data yang digunakan $(\mathrm{N})$ sebanyak 5 , sehingga dari tabel diperoleh nilai rata-rata sebesar Rp 172.208.324.866,8080. Sedangkan untuk nilai standar deviasinya yaitu sebesar Rp 316.910.865.641,21967.

\section{Uji Asumsi Klasik}

\section{a. Uji Normalitas}

Sebelum memberikan interprestasi pada hasil regresi, dilakukan pengujian asumsi normalitas sebagai syarat regresi. Apabila berdistribusi normal maka analisis parametrik seperti analisis regresi dapat dilanjutkan, sebaliknya apabila tidak berdistribusi normal maka digunakan statistik non-parametrik untuk menguji hipotesis. Pengujian normalitas ini menggunakan diagram histogram dan grafik normal probability plot untuk memprediksi apakah residual berdistribusi normal atau tidak.

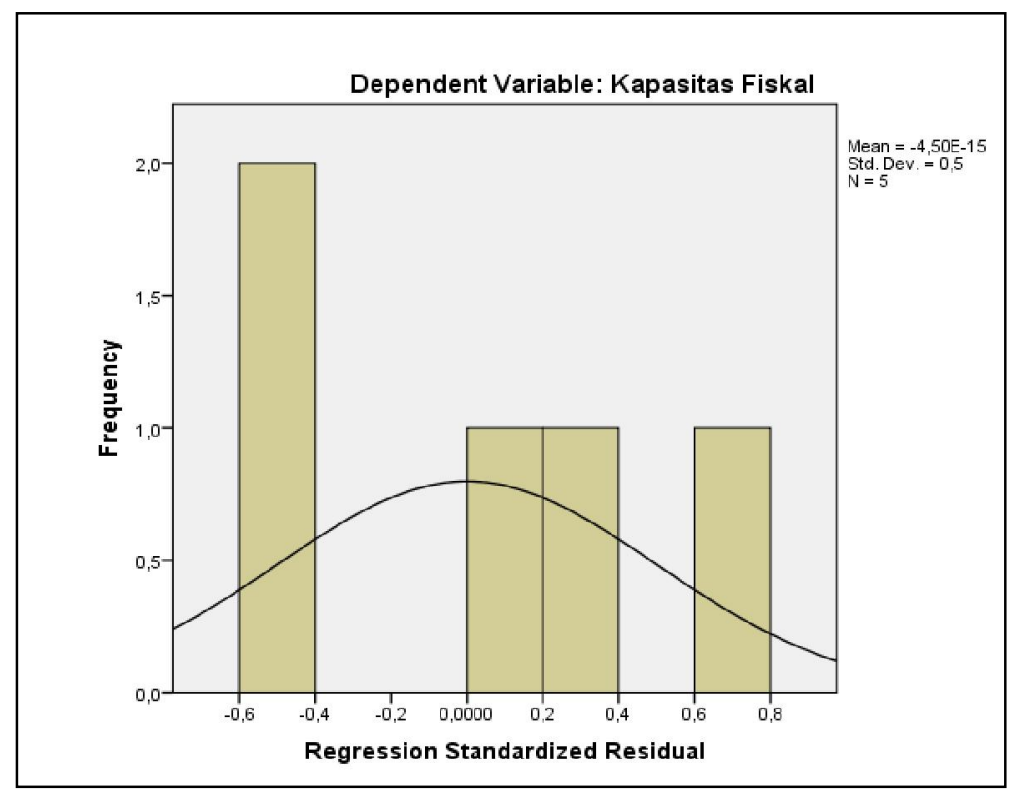

Gambar 2. Histogram

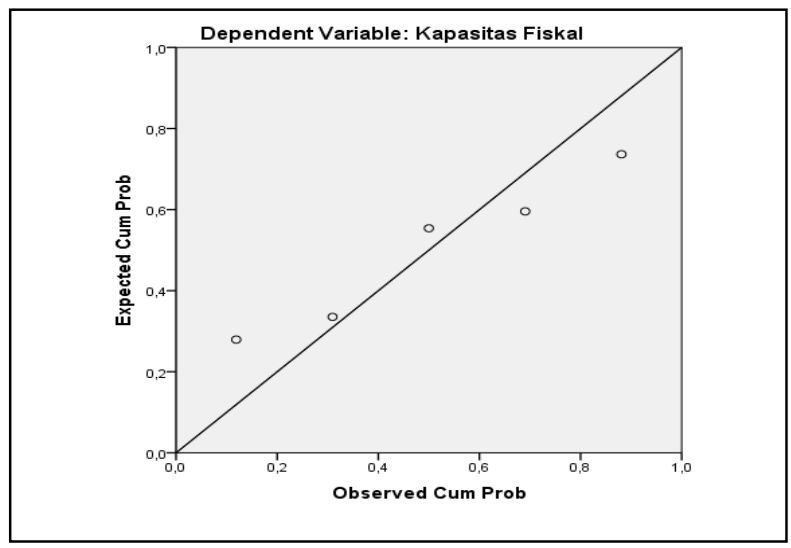

Gambar 3. Normal P-P Plot of Regression Standardized Residual 
Berdasarkan hasil uji diatas, dengan melihat tampilan grafik histogram pada Gambar 2 maupun grafik normal probability plot pada Gambar 3 dapat disimpulkan bahwa grafik histogram memberikan pola distribusi yang tidak lurus ke kiri dan tidak normal sedangkan pada grafik normal p-p plot menunjukkan titik-titik variabel menyebar menjauhi garis. Kedua grafik tersebut menunjukkan bahwa model regresi menyalahi asumsi normalitas.

Selain pengujian dengan grafik, normalitas data juga dapat diuji secara statistik dengan menggunakan uji Kolmogorov-Smirnov (Uji K-S) yang terdapat pada Tabel 3 berikut ini:

Tabel 3. Hasil K-S One-Sample Kolmogorov-Smirnov Test

\begin{tabular}{|c|c|c|}
\hline & & $\begin{array}{l}\text { Unstandardized Predicted } \\
\text { Value }\end{array}$ \\
\hline $\mathrm{N}$ & & 5 \\
\hline \multirow{3}{*}{ Normal Parameters ${ }^{\mathrm{a}, \mathrm{b}}$} & Mean & $172.208 .324 .866,8087200$ \\
\hline & Std. & $306.487 .192 .926,7114000$ \\
\hline & Deviation & 0 \\
\hline \multirow{3}{*}{ Most Extreme Differences } & Absolute &, 355 \\
\hline & Positive &, 355 \\
\hline & Negative & $\begin{array}{l}-, 201 \\
-, 21\end{array}$ \\
\hline Kolmogorov-Smirnov Z & &, 795 \\
\hline Asymp. Sig. (2-tailed) & &, 553 \\
\hline \multicolumn{3}{|l|}{ a. Test distribution is Normal. } \\
\hline
\end{tabular}

Dari hasil uji Kolmogorov-Smirnov pada Tabel 3 dapat diketahui bahwa unstandardized residual memiliki nilai signifikan sebesar 0,553, lebih besar dari nilai signifikan yaitu $0,05(0,553>0,05)$, sedangkan besarnya nilai Kolmogorov-Smirnov adalah 0,795 , lebih besar dari nilai signifikannya $(0,795>0,05)$, sehingga dalam pengujian ini dapat disimpulkan bahwa pajak daerah, retribusi daerah, produk domestik regional bruto dan kapasitas fiskal berdistribusi normal, maka hasil analisis ini dapat lanjut ke analisis regresi karena syarat dalam uji asumsi klasik nilai residualnya sudah terpenuhi atau dinyatakan normal.

\section{b. Uji Multikolonieritas}

Uji multikolonieritas dilakukan dengan cara melihat nilai tolerance dan VIF untuk melihat keadaan dimana ketiga variabel independen terjadi hubungan linier yang sempurna atau mendekati sempurna. Hasil pengujian dapat dilihat pada Tabel 4 berikut: 
Tabel 4. Hasil Multikolonieritas Coefficients

\begin{tabular}{|c|c|c|c|}
\hline \multicolumn{2}{|c|}{ Model } & \multicolumn{2}{|c|}{ Collinearity Statistics } \\
\hline & & Tolerance & VIF \\
\hline \multirow{4}{*}{1} & (Constant) & & \\
\hline & Pajak Daerah & 003 & 293,352 \\
\hline & Retribusi Daerah & ,234 & 4,266 \\
\hline & PDRB & 003 & 297,476 \\
\hline
\end{tabular}

Tabel 4 diatas menunjukkan bahwa variabel retribusi daerah memiliki nilai Tolerance $>0,10$ dan VIF $<10$ sehingga hasil ini menunjukkan bahwa retribusi daerah memiliki korelasi antar variabel atau dengan kata lain terjadi multikolonieritas antar variabel, sedangkan variabel lainnya tidak terjadi multikolonieritas.

\section{c. Uji Heteroskedastisitas}

Pada pengujian heteroskedastisitas bertujuan untuk mengetahui ada tidaknya heteroskedastisitas atau ketidaksamaan varian dari model regresi sebelumnya yang dapat dilihat dari grafik scatterplot pada Gambar 5 berikut ini:

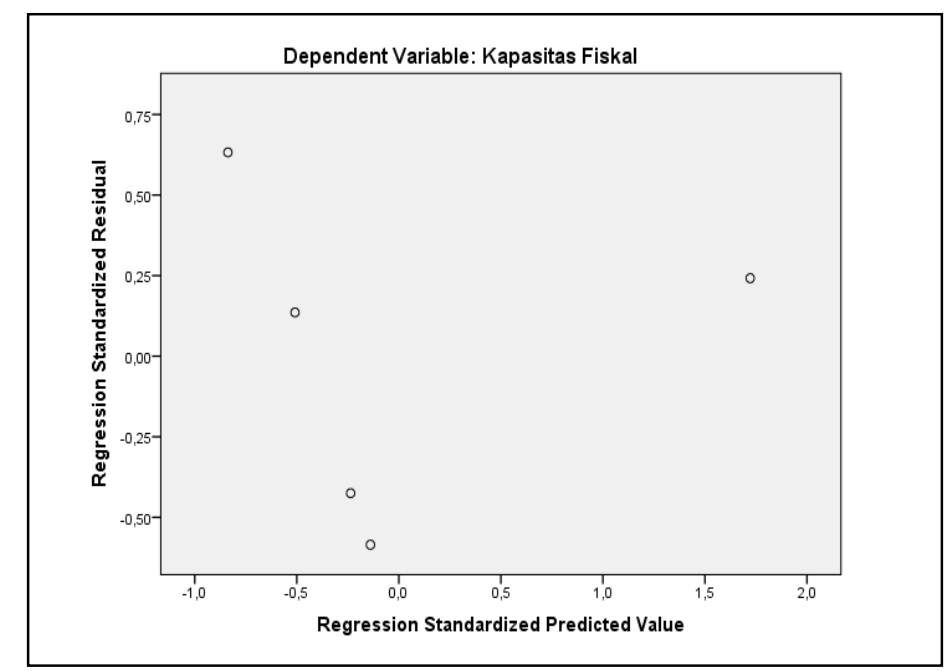

Gambar 5. Hasil Heteroskedastisitas Scatterplot

Berdasarkan dari hasil uji grafik Scatterplot pada Gambar 5 diatas, menunjukkan bahwa tidak terjadinya heteroskedastisitas pada model regresi. Hal ini terlihat dari titiktitik yang menyebar secara acak dan tidak saling berhimpitan yang terdapat diatas maupun dibawah angka 0 pada sumbu Y. 


\section{d. Uji Autokorelasi}

Uji ini berguna untuk menguji keadaan dimana terjadinya korelasi dari residual untuk model regresiyang disusun menurut runtun waktu terentu. Hasil uji autokorelasi dapat dilihat pada Tabel 5 berikut ini:

Tabel 5. Hasil Autokorelasi Model Summary

\begin{tabular}{|c|c|c|c|c|c|}
\hline \multirow[t]{2}{*}{ Model } & Unstandardized & Coefficients & \multirow{2}{*}{$\begin{array}{c}\text { Standardiz } \\
\text { ed } \\
\text { Coefficien } \\
\text { ts } \\
\text { Beta }\end{array}$} & \multirow[t]{2}{*}{$\mathrm{t}$} & \multirow[t]{2}{*}{ Sig. } \\
\hline & B & Std. Error & & & \\
\hline (Constant) & $\begin{array}{r}2.362 .864 .892 .5 \\
76,584\end{array}$ & $\begin{array}{r}709.623 .088 .9 \\
77,844\end{array}$ & & 3,330 & , 186 \\
\hline Pajak Daerah & $-27,449$ & 34,420 & $-3,474$ &,- 797 & ,571 \\
\hline $\begin{array}{l}\text { Retribusi } \\
\text { Daerah }\end{array}$ & $-28,216$ & 14,970 &,- 990 & $-1,885$ & ,311 \\
\hline PDRB & $211.076,629$ & $324.597,201$ & 2,853 &, 650 & ,633 \\
\hline
\end{tabular}

Berdasarkan Tabel 5 diatas diketahui bahwa nilai DW sebesar 1,834, nilai ini dibandingkan dengan nilai tabel dengan menggunakan nilai signifikan 5\%. Jumlah variabel independen $3(\mathrm{k}=3)$ dan jumlah observasi sebanyak $5(\mathrm{n}=5)$ maka dari tabel Durbin Watson akan diperoleh nilai dL dan nilai dU. Oleh karena jumlah observasi pada penelitian ini hanya sebanyak 5 maka besarnya nilai dL dan dU tidak dapat diketahui, sehingga dapat disimpulkan bahwa $\mathrm{dL} \leq \mathrm{dW} \leq \mathrm{dU}$ berarti tidak dapat mengambil keputusan apakahautokorelasi positif terjadi atau tidak.

\section{e. Analisis Regresi}

Model regresi adalah model analisis data menggunakan asumsi dan arti persamaan regresi sederhana yang berlaku pada regresi ganda, sesuai dengan model yang digunakan pada penelitian ini yaitu model regresi berganda dengan 3 variabel untuk melihat pengaruh pajak daerah, retribusi daerah dan PDRB terhadap kapasitas fiskal. Adapun formula regresi berganda sebagai berikut:

$$
Y=a+b_{1} X_{1}+b_{2} X_{2}+b_{3} X_{3}
$$

Tabel 6. Hasil Analisis Regresi Berganda Coefficients

\begin{tabular}{|c|c|c|c|c|c|}
\hline Model & $\mathrm{R}$ & $\begin{array}{c}\mathrm{R} \\
\text { Square }\end{array}$ & $\begin{array}{l}\text { Adjusted } \\
\text { R Square }\end{array}$ & $\begin{array}{l}\text { Std. Error of the } \\
\text { Estimate }\end{array}$ & $\begin{array}{l}\text { Durbin- } \\
\text { Watson }\end{array}$ \\
\hline 1 &, $967^{\mathrm{a}}$ & ,935 &, 741 & $\begin{array}{r}161.221 .553 .563,6 \\
8860\end{array}$ & 1,834 \\
\hline $\begin{array}{l}\text { a. Predi } \\
\text { Pajak D }\end{array}$ & rs: (Co & nstant), P & DRB, Retri & usi Daerah, & \\
\hline
\end{tabular}


Hasil analisis model regresi berganda dapat ditulis sebagai berikut:

$$
\mathrm{Y}=2.362 .864 .892 .576,584-27,449 \mathrm{X}_{1}-28,216 \mathrm{X}_{2}+211.076,629 \mathrm{X}_{3}
$$

Berdasarkan Tabel 6 dan rumus diatas diketahui bahwa nilai konstanta adalah sebesar 2.362.864.892.576,584, artinya apabila nilai variabel pajak daerah, retribusi daerah dan produk domestik regional bruto bernilai 0, maka kapasitas fiskal akan bertambah sebesar 2.362.864.892.576,584. Variabel pajak daerah, menunjukkan adanya pengaruh terhadap kapasitas fiskal dengan pola negatif sehingga apabila pajak daerah bertambah maka semakin rendah kapasitas fiskal dengan nilai koefisien sebesar -27,449, artinya setiap pertambahan 1 (satu) rupiah pada variabel pajak daerah mengakibatkan penurunan pada kapasitas fiskal sebesar -27,449.

Variabel retribusi daerah, menunjukkan adanya pengaruh terhadap kapasitas fiskal dengan pola negatif sehingga apabila retribusi daerah bertambah maka semakin rendah kapasitas fiskal dengan nilai koefisien sebesar -28,216, artinya setiap pertambahan 1 (satu) rupiah pada variabel retribusi daerah mengakibatkan penurunan pada kapasitas fiskal sebesar -28,216. Variabel Produk Domestik Regional Bruto (PDRB), menunjukkan adanya pengaruh terhadap kapasitas fiskal dengan pola positif sehingga apabila pajak daerah bertambah maka semakin rendah kapasitas fiskal dengan nilai koefisien sebesar 211.076,629, artinya setiap pertambahan 1 (satu) rupiah pada variabel PDRB mengakibatkan penambahan pada kapasitas fiskal sebesar 211.076,629.

\section{f. Uji-F (simultan)}

Uji ini digunakan untuk mengetahui apakah variabel independen secara bersamaan mempengaruhi variabel dependen. Pengujian ANOVA atau Uji-F bisa dilakukan dengan dua cara yaitu dengan melihat tingkat signifikansi dan dengan membandingkan F-hitung dengan F-tabel. Pengujian dengan tingkat signifikansi dilakukan dengan ketentuan yaitu apabila hasil signifikansi pada tabel ANOVA $<\alpha 0,05$, maka Ho ditolak (berpengaruh), sementara sebaliknya apabila tingkat signifikansi pada tabel ANOVA $>\alpha 0,05$, maka Ho diterima (tidak berpengaruh).

Sedangkan untuk pengujian dengan membandingkan F-hitung dengan F-tabel dilakukan dengan ketentuan yaitu jika F-hitung < F-tabel maka Ho diterima (tidak berpengaruh), sedangkan jika F-hitung $>$ F-tabel makaHo ditolak (berpengaruh). Hasil uji tersebut disajikan pada Tabel 7 sebagai berikut:

\section{Tabel 7. Uji-F}

\begin{tabular}{|c|c|c|c|c|c|c|}
\hline Model & & Sum of Squares & Df & Mean Square & $\mathrm{F}$ & Sig. \\
\hline \multirow{3}{*}{1} & Regression & $3,757 \mathrm{E}+23$ & 3 & $1,252 \mathrm{E}+23$ & 4,819 &, $320^{\mathrm{b}}$ \\
\hline & Residual & $2,599 \mathrm{E}+22$ & 1 & $2,599 \mathrm{E}+23$ & & \\
\hline & Total & $4,017 E+23$ & 4 & & & \\
\hline
\end{tabular}


Tabel 7 menunjukkan hasil uji-F dengan nilai F-hitung sebesar 4,819 dan nilaisignifikansi sebesar 0,320 $(>0,05)$. Diketahui nilai signifikan ANOVA $>0,05$ $(0,320>0,05)$ maka Ho diterima (tidak berpengaruh). Untuk nilai F-hitung, akan dibandingkan dengan nilai F-tabel yang diperoleh melalui fungsi FINV pada Microsoft Excel atau pun dengan melihat tabel-F yang dapat dicari dengan rumus berikut:

$$
\begin{aligned}
& \mathrm{df} 1=\mathrm{k}-1=3-1=2 \\
& \mathrm{df} 2=\mathrm{n}-\mathrm{k}=5-3=2
\end{aligned}
$$

dimana:

df1 $\quad=$ Distribusi Persentase Pembilang (N1)

df2 $=$ Distribusi Persentase Penyebut (N2)

$\mathrm{k} \quad=$ Jumlah Variabel

$\mathrm{n} \quad=$ Jumlah Data

signifikan $=0,05$.

Hasilnya diketahui bahwa besar nilai F-tabel untuk FINV $(0,05,2,2)$ adalah 19. Nilai F-hitung $<$ F-tabel $(4,819<19)$ maka Ho diterima (tidak berpengaruh). Hal ini menunjukkan bahwa variabel Pajak Daerah, Retribusi Daerah, dan Produk Domestik Regional Bruto secara simultan signifikan tidak berpengaruh terhadap variabel Kapasitas Fiskal.

\section{g. Uji-t (parsial)}

Uji statistik t disebut juga sebagai uji signifikasi individual. Uji ini menunjukkan seberapa jauh pengaruh variabel independen secara parsial terhadap variabel dependen. Pengaruh pajak daerah, retribusi daerah dan PDRB secara parsial terhadap kapasitas fiskal dapat diketahui dari hasil uji-t yang terdapat pada Tabel 8.

Tabel 8 menunjukkan hasil uji-t dengan nilai t-hitung variabel pajak daerah sebesar -0,797 dengan nilai signifikan sebesar 0,571, nilai signifikan menunjukkan diatas tingkat signifikan sebesar $0,05(0,571>0,05)$. Untuk nilai t-hitung variabel retribusi daerah sebesar $-1,885$ dengan nilai signifikan sebesar 0,311, nilai signifikan menunjukkan diatas tingkat signifikan sebesar $0,05(0,311>0,05)$, sedangkan untuk nilai t-hitung variabel PDRB sebesar 0,650 dengan nilai signifikan sebesar 0,633, nilai signifikan menunjukkan diatas tingkat signifikan sebesar $0,05(0,633>0,05)$. 
Tabel 8. Uji-t Coefficients

\begin{tabular}{|c|c|c|c|c|c|}
\hline \multirow{2}{*}{\multicolumn{2}{|c|}{ Model }} & \multicolumn{2}{|c|}{$\begin{array}{l}\text { Unstandardized } \\
\text { Coefficients }\end{array}$} & \multirow{2}{*}{$\mathrm{t}$} & \multirow{2}{*}{ Sig. } \\
\hline & & $\mathrm{B}$ & Std. Error & & \\
\hline \multirow{4}{*}{1} & (Constant) & $\begin{array}{r}2.362 .864 .892 \\
.576,584\end{array}$ & $\begin{array}{r}709.623 .08 \\
8.977,844\end{array}$ & 3,330 &, 186 \\
\hline & Pajak Daerah & $-27,449$ & 34,420 &,- 797 &, 571 \\
\hline & Retribusi Daerah & $-28,216$ & 14,970 & $-1,885$ &, 311 \\
\hline & PDRB & 211076,629 & $\begin{array}{r}324597,20 \\
1\end{array}$ & ,650 & ,633 \\
\hline
\end{tabular}

Nilai t-hitung akan dibandingkan dengan nilai t-tabel yang diperoleh melalui fungsi TINV pada Microsoft Excel atau pun dengan melihat tabel-t yang dapat dicari dengan rumus berikut:

$$
\mathrm{df}=\mathrm{n}-\mathrm{k}-1=5-3-1=1
$$

dimana:

$\begin{array}{ll}\mathrm{df} & =\text { Distribusi Persentase } \\ \mathrm{k} & =\text { Jumlah Variabel } \\ \mathrm{n} & =\text { Jumlah Data } \\ \text { signifikan } & =0,05\end{array}$

Hasilnya diketahui bahwa besar nilai t-tabel untuk TINV $(0,05,1)$ adalah 12,7062 , maka: Variabel Pajak Daerah, memiliki nilai t-hitung $<$ t-tabel $(-0,797<12,7062)$ maka Ho diterima (tidak berpengaruh). Hal ini menunjukkan bahwa variabel Pajak Daerah, secara parsial signifikan tidak berpengaruh terhadap variabel kapasitas fiskal. Variabel Retribusi Daerah, memiliki nilai t-hitung $<$ t-tabel $(-1,885<12,7062)$ maka Ho diterima (tidak berpengaruh). Hal ini menunjukkan bahwa variabel retribusi daerah, secara parsial signifikan tidak berpengaruh terhadap variabel kapasitas fiskal. Variabel Produk Domestik Regional Bruto, memiliki nilai t-hitung $<$ t-tabel $(0,650<12,7062)$ maka Ho diterima (tidak berpengaruh). Hal ini menunjukkan bahwa variabel produk domestik regional bruto, secara parsial signifikan tidak berpengaruh terhadap variabel kapasitas fiskal.

Dari penjelasan diatas dapat disimpulkan bahwa ketiga variabel (pajak daerah, retribusi daerah, dan produk domestik regional bruto) memiliki probabilitas signifikansi diatas 0,05 , sehingga dapat diketahui bahwa kapasitas fiskal tidak dipengaruhi oleh ketiga variabel independen yang diteliti. Persamaan matematis dapat ditulis : 
$Y=2.362 .864 .892 .576,584-27,449 X_{1}-28,216 X_{2}+211.076,629 X_{3}$

\section{h. Koefisien Determinan (Adjusted R Square)}

Koefisien Determinan digunakan untuk mengetahui seberapa besar pengaruh dari variabel independen terhadap variabel dependen. Besarnya nilai koefisien determinasi dapat ditentukan dengan nilai Adjusted $R$ Square yang dapat dilihat pada Tabel 9 berikut:

Tabel 9. Model Summary

\begin{tabular}{|c|c|c|c|c|}
\hline Model & $\mathrm{R}$ & R Square & $\begin{array}{c}\text { Adjusted R } \\
\text { Square }\end{array}$ & Std. Error of the Estimate \\
\hline 1 & $\begin{array}{r}96 \\
7^{\mathrm{a}}\end{array}$ & ,935 & ,741 & $161.221 .553 .563,68860$ \\
\hline \multicolumn{5}{|c|}{ a. Predictors: (Constant), PDRB, Retribusi Daerah, Pajak Daerah } \\
\hline \multicolumn{5}{|c|}{ b. Dependent Variable: Kapasitas Fiskal } \\
\hline
\end{tabular}

Berdasarkan hasil perhitungan koefisien determinan pada Tabel 9 diatas, diketahui bahwa besar nilai koefisien determinan adalah 0,741. Sesuai dengan nilai Adjusted $R$ Squarepada tabel diatas dinyatakan bahwa 74,1\% variabel dependen (kapasitas fiskal) dapat dipengaruhi oleh variabel independen (pajak daerah, retribusi daerah dan PDRB), sedangkan sisanya yaitu sebesar 25,9\% dapat dipengaruhi oleh variabel lain diluar model penelitian ini.

\subsection{Pengaruh Pajak Daerah, Retribusi Daerah dan Produk Domestik Regional Bruto Terhadap Kapasitas Fiskal Kota Pontianak}

Untuk mengetahui pengaruh dari variabel independen terhadap variabel dependen dapat dilihat pada Tabel 10 hasil pengujian variabel yang menggunakan aplikasi olah data SPSS v.20 sebagai berikut:

Tabel 10. Hasil Pengujian Variabel Independen

\begin{tabular}{lcccc}
\multicolumn{1}{c}{ Uji Simultan } & \multicolumn{2}{c}{ Uji Parsial } \\
\multicolumn{1}{c}{ Variabel } & F-hitung & F-tabel & t-hitung & t-tabel \\
& & & -0.797 & \\
\hline $\begin{array}{l}\text { Pajak Daerah } \\
\text { Retribusi }\end{array}$ & 4.819 & 19 & -1.885 & 12.7062 \\
Daerah & & & & \\
\hline PDRB & & & 0.65 &
\end{tabular}

Berdasarkan hasil pengujian yang disajikan dalam Tabel 10, hasil analisis secara simultan, menunjukkan bahwa variabel pajak daerah, retribusi daerah dan PDRB secara 
bersama-sama tidak berpengaruh terhadap kapasitas fiskal yang dijelaskan nilai F-hitung 4,819 < F-tabel 19, hal ini bermakna kapasitas fiskal Kota Pontianak tahun 2012-2016 tidak sepenuhnya dipengaruhi oleh pajak daerah, retribusi daerah maupun PDRB. Hasil penelitian ini diperkuat dengan hasil uji koefisien determinasi yaitu sebesar $74,1 \%$ kapasitas fiskal dipengaruhi oleh pajak daerah, retribusi daerah dan PDRB, sedangkan 25,9\% kapasitas fiskal ditentukan oleh variabel lain yang tidak dibahas dalam penelitian ini.

Selain analisis secara simultan, untuk melihat seberapa besar pengaruh dari masing-masing variabel independen terhadap variabel dependen dapat diketahui dari anilisis secara parsial yang menjelaskan seberapa besar pengaruh satu-persatu dari variabel independen terhadap variabel dependen. Hasil analisis tersebut dijelaskan berdasarkan data sebelumnya yang telah diuji menggunakan aplikasi SPSS v.20 sehingga hasil analisis parsial dijelaskan sesuai dengan hasil uji parsial yang telah dilakukan dalam penelitian ini.

\section{Pengaruh Pajak Daerah Terhadap Kapasitas Fiskal Kota Pontianak}

Berdasarkan penelitian yang telah dilakukan, diperoleh hasil bahwa variabel pajak daerah secara parsial tidak berpengaruh terhadap kapasitas fiskal yang diketahui dari hasil hitung antara nilai t-hitung dan t-tabel dengan hasil nilai t-hitung $<\mathrm{t}$-tabel $(-0,797<12,7062)$, artinya variabel pajak daerah diterima dikarenakan nilai t-hitung lebih kecil daripada t-tabel sehingga mengakibatkan tidak adanya pengaruh yang signifikan terhadap kapasitas fiskal. Hal ini menyatakan bahwa pajak daerah bukan satusatunya variabel terbesar yang mempengaruhi kemampuan ekonomi suatu daerah, karena dalam PAD masih banyak pendapatan-pendapatan lain yang dimiliki oleh daerah untuk memenuhi kegiatan pembangunan yang dilakukan oleh pemerintah daerah Kota Pontianak untuk memfasilitasi pembiayaan yang digunakan.

Berdasarkan hasil persamaan regresi, pajak daerah memiliki pengaruh negatif terhadap kapasitas fiskal sehingga apabila pajak daerah bertambah 1 (satu) rupiah mengakibatkan penurunan pada kapasitas fiskal sebesar -27,449. Hal ini menyatakan bahwa naik turunnya nilai realisasi pajak daerah memberikan pengaruh terhadap pendapatan dan alokasi-alokasi belanja suatu daerah yang mendukung infrastruktur belanja publik dalam memenuhi kebutuhan ekonomi masyarakat.

\section{Pengaruh Retribusi Daerah Terhadap Kapasitas Fiskal Kota Pontianak}

Berdasarkan penelitian yang telah dilakukan, diperoleh hasil bahwa variabel retribusi daerah secara parsial tidak berpengaruh terhadap kapasitas fiskal yang diketahui dari hasil hitung antara nilai t-hitung dan t-tabel dengan hasil nilai t-hitung $<$ t-tabel $(-1,885<12,7062)$, artinya variabel retribusi daerah diterima dikarenakan nilai t-hitung lebih kecil daripada t-tabel sehingga mengakibatkan tidak adanya pengaruh yang 
signifikan terhadap kapasitas fiskal. Hal ini menyatakan bahwa retribusi daerah bukan satu-satunya variabel terbesar yang mempengaruhi kemampuan ekonomi suatu daerah.

Berdasarkan hasil persamaan regresi, retribusi daerah memiliki pengaruh negatif terhadap kapasitas fiskal sehingga apabila retribusi daerah bertambah 1 (satu) rupiah mengakibatkan penurunan pada kapasitas fiskal sebesar -28,216. Hal ini menyatakan bahwa naik turunnya nilai realisasi retribusi daerah memberikan pengaruh terhadap pendapatan suatu daerah dan alokasi-alokasi belanja yang mendukung infrastruktur belanja publik dalam memenuhi kebutuhan ekonomi masyarakat.

\section{Pengaruh Produk Domestik Regional Bruto Terhadap Kapasitas Fiskal Kota Pontianak}

Berdasarkan penelitian yang telah dilakukan, diperoleh hasil bahwa variabel PDRB secara parsial tidak berpengaruh terhadap kapasitas fiskal yang diketahui dari hasil hitung antara nilai t-hitung dan t-tabel dengan hasil nilai t-hitung $<$ t-tabel $(0,650<$ 12,7062), artinya variabel PDRB diterima dikarenakan nilai t-hitung lebih kecil daripada t-tabel sehingga mengakibatkan tidak adanya pengaruh yang signifikan terhadap kapasitas fiskal. Hal ini menyatakan bahwa PDRB bukan satu-satunya variabel terbesar yang mempengaruhi kemampuan ekonomi suatu daerah.

Berdasarkan hasil persamaan regresi, PDRB memiliki pengaruh positif terhadap kapasitas fiskal sehingga apabila PDRB bertambah 1 (satu) rupiah mengakibatkan penurunan pada kapasitas fiskal sebesar 211.076,629. Hal ini menyatakan bahwa naik turunnya nilai PDRB memberikan pengaruh terhadap kapasitas fiskal, dikarenakan pertumbuhan perekonomian dihitung menggunakan PDRB sehingga apabila perekonomian Kota Pontianak meningkat maka PDRB juga akan ikut meningkat, begitu juga sebaliknya. Penentuan besarnya PDRB Kota Pontianak dilihat dari besarnya omset pendapatan dari sektor-sektor PDRB itu sendiri yang menjadi potensi dari daerah tersebut sebagai pengukur tingkat kemajuan daerah yang dikelola oleh masyarakat.

\section{SIMPULAN}

Dalam uji-F dapat diketahui bahwa variabel pajak daerah, retribusi daerah dan PDRB signifikan ANOVA lebih besar daripada signifikan 0,05, menunjukkan bahwa ketiga variabel bersama-sama tidak berpengaruh terhadap kapasitas fiskal atau variabel dependen. Hasil ini terlihat dari nilai signifikansi sebesar 0,320 $(>0,05)$, sedangkan untuk nilai F-hitung $<$ F-tabel $(4,819<18,51)$ maka Ho diterima (tidak berpengaruh). Sedangkan uji-t dapat diketahui bahwa tiga variabel (pajak daerah, retribusi daerah dan PDRB) memiliki probabilitas signifikansi diatas 0,05 yaitu $(0,571,0,311$ dan 0,633$)$, sedangkan untuk nilai t-hitung $<$ t-tabel $(-0,797,(-1,885$ dan $0,650<4.30265)$ artinya secara parsial kapasitas fiskal tidak dipengaruhi oleh ketiga variabel independen. Keterbatasan dari riset ini adalah sumber jurnal yang terbatas khususnya internasional karena perbedaan peraturan keuangan dan pajak daerah di luar negeri tentunya pada 
praktiknya secara teknis pelaksanaannya dengan di Indonesia khususnya di Kota Pontianak.

\section{DAFTAR PUSTAKA}

Chodariyanti, L. (2015). Analisis Kebutuhan Fiskal dan Kapasitas Fiskal Kabupaten Lamongan Tahun 2009-2013. Jurnal Ekbis, XIV(2), 677-689.

Dewi, J.K., Budhi, M. K. . (2018). Analisis Pengaruh Pajak Daerah, Retribusi Daerah Terhadap Tenaga Kerja Dan Pertumbuhan Ekonomi di Kota Palang Karaya Provinsi Kalimantan Tengah. E-Jurnal Ekonomi Dan Bisnis Universitas Udayana, 7 (6), $1695-1722$.

Fiona, L., Taufik, T, \& Ratnawati, V. (2016). Analisis Kapasitas Fiskal dan Pengaruhnya Terhadap Anggaran Belanja Modal pada Pemerintah Daerah di Sumatera. Jurnal Ekonomi, XXI(2), 232-247.

Habiburrahman. (2012). Analisis Pengaruh Produk Domestik Regional Bruto (PDRB) terhadap Penyerapan Tenaga Kerja. Manajemen Dan Bisnis, 3(1), 101-114.

Herdaleny, A., Badjuri, Prianto, F. . (2015). Analisis Kapasitas Fiskal dan Peranannya Terhadap PDRB (Studi Kasus Kabupaten/Kota di Jawa Timur) (Analysis fiscal capacity and roles against PDRB) (a case study district/cities in east java), 1-7.

Juwari, J., Djoko, S., Yana, U. (2016). Juwari, D. S. (2016). Pengaruh Pajak dan Retribusi Serta DAU dan DAK terhadap Belanja Daerah dan Pertumbuhan Ekonomi Pada Kabupaten/Kota. Jurnal GeoEkonomi . GeoEkonomi, 7(1), 01-15.

Kusuma, M.K.A.A \& Wirawati, N. G. . (2013). Analisis Pengaruh Penerimaan Pajak Daerah dan Retribusi Daerah Terhadap Peningkatan PAD Sekabupaten/Kota di Provinsi Bali. E-Jurnal Akuntansi Universitas Udayana, 5(3), 574-585.

Mafaza, W., Mayowan, Y., Sasetiadi., T. . (2016). Kontribusi Pajak Daerah dan Retribusi Daerah dalam Pendapatan Asli Daerah. Jurnal Perpajakan, 11(1), 1-4.

Menteri Keuangan. Peraturan Menteri Keuangan Republik Indonesia Nomor 119/PMK.07/2017 Tentang Peta Kapasitas Fiskal (2017). Jakarta.

Nurhayati. (2016). Analisis penerimaan pajak daerah dan pengaruhnya terhadap pendapatan perkapita Kota Jambi. Perspektif Ekonomi dan Pembangunan Daerah . E-Jurnal Perspektif Ekonomi Dan Pembangunan Daerah, 5 (1).

Rauf, A. A. (2016). Kapasitas Fiskal dan PDRB dengan Tingkat Kemiskinan: Studi pada Kabupaten/Kota di Sulawesi Tengah. E-Jurnal Katalogis, 4(10), 64-81.

Sari, D. (2013). Konsep Dasar Perpajakan. Bandung: Refika Aditama.

Sunarto \& Sunyoto, S. (2016). Pengaruh Pajak Daerah Dan Retribusi Daerah Terhadap Kemadirian Daerah Yang Berdampak Pada Pertumbuhan Ekonomi Daerah (Studi Empiris Pada Kabupaten dan Kota di Jawa Tengah). Dharma Ekonomi, No.43, 1322.

Widani, C. I. K, \& Erawati, N. M. A. (2016). Pengaruh Kapasitas Fiskal Daerah dan Pertumbuhan Ekonomi Daerah pada Indeks Pembangunan Manusia. E-Jurnal Akuntansi Universitas Udayana, 17(1), 203-232. 